\title{
EMPOWERING TEACHER ENGAGEMENT IN PRIMARY SCHOOLS THROUGH VIDEO INTERVENTION PROGRAM
}

\author{
${ }^{1}$ Sucianna Ghadati Rabiha, ${ }^{2}$ Sasmoko, ${ }^{3}$ Yasinta Indrianti \\ ${ }^{1}$ Binus Online Learning \& Research Interest Group in Educational \\ Technology, Information Systems Department. \\ ${ }^{2}$ Primary Teacher Education Department, Faculty Humanities \& Research Interest Group in \\ Educational Technology \\ ${ }^{3}$ Research Interest Group in Educational Technology, \\ Bina Nusantara University \\ *sasmoko@binus.edu
}

Received: January $19^{\text {th }}, 2021 /$ Revised: February $18^{\text {th }} 2020 /$ Accepted: March $12^{\text {th }}, 2020$

\begin{abstract}
Teacher engagement basically shows that the personal and existence of a qualified teacher is positioned not only as a teacher but as an integrated whole of an educator who is professional and has an Indonesian character. This concept is in line with the mandate of the 2015-2019 RPJMN as stipulated in the Ministry of Research and Technology Strategic Plan where the government seeks to strengthen overall development by emphasizing the development of economic competitive advantages, one of which is based on quality institutions and resources. Based on the results of the trials conducted, it can be concluded that the engagement of elementary school teachers in Jakarta, Bekasi and South Tangerang can be increased through the Video Intervention Program. After empowering teachers through the Video Intervention Program, elementary school teachers in Jakarta, Bekasi and South Tangerang experienced significant engagement at $\alpha<0.05$. Furthermore, through the results of the self-assessment, it was found that teacher empowerment through the Video Intervention Program will further increase teacher engagement in Jakarta, Bekasi and South Tangerang, if these teachers improve themselves in carrying out religious orders.
\end{abstract}

Keywords: teacher engagement, self-assessment

\section{Introduction.}

A study states that current education management must position itself as a modern educational management capable of implementing a reward and punishment system so as to ensure excellent performance from teachers and institutions to strengthen results and productivity (Suleman, 2012). Teachers in Indonesia are professional educators with the main task of educating, teaching, guiding, directing, training, assessing, and evaluating students in early childhood education formal education, basic education and secondary education (Undang Undang Republik Indonesia No 14 Tahun 2005 tentang Guru dan Dosen, 2005). The existence of teachers in Indonesia is very important in improving the standard of living of the nation by involving all spiritual, emotional, intellectual, physical and other aspects (Suparlan \& Ed, 2005).

Teacher engagement basically shows that the personal and existence of a qualified teacher is positioned not only as a teacher but as a whole as a professional educator with Indonesian character. This concept is in line with the mandate of the third RPJMN for 2015-2019 which is stated in the Ministry of Research, Technology and Higher Education's Strategic Plan where the government seeks to solidify overall development by emphasizing the development of competitive economic advantages, one of which is based on quality institutions and resources. 
This effort provides benefits for every education actor starting from the Ministry of Education and Culture of the Republic of Indonesia, especially the Directorate General of Primary and Secondary Education, formal education institutions and the human resources involved. These benefits are in the form of anatomical portraits of teachers and educational institutions so that appropriate interventions are obtained in order to improve sustainable quality. Based on the analysis, the aim of this Community Service is to carry out "Empowerment of Primary School Teacher Engagement in Jakarta, Bekasi and South Tangerang".

A synergistic effort to achieve the best student achievement as an indicator of the quality of education is the full and deep involvement and engagement of the teacher as the key (Beairsto Bruce, 2012). This community service program tries to build a teacher engagement construct in the Indonesian context in accordance with the Third RPJMN 2015-2019, the Ministry of Research, Technology and Higher Education Strategic Plan and also the 2015-2019 Bina Nusantara University Research Strategic Plan, so that it is able to detect early portraits of teachers in Indonesia, especially primary school teachers in Jakarta, Bekasi and South Tangerang.

Through the Community Service Program, we try to provide an understanding regarding Teacher Engagement through Intervention Videos that we share on YouTube. So that teachers can understand the concepts in Teacher Engagement. In addition, we also ask for feedback from teachers to conduct self-assessment of understanding related to Teacher Engagement through the google form application. With early detection, it will be followed by the ability to make relatively appropriate interventions as a strategic effort in building 21 st century teachers who are ready to compete internationally and be able to produce quality future generations.

\section{Literature Review.}

The Indonesian teachers involved are positioned not only as teachers, but also helping to shape the professional characteristics of an Indonesian educator model. Research on teacher engagement proves that it has a positive impact on student education. Engaged teachers can also make students more involved, thus creating a more effective learning atmosphere (Louis, Seashore, Smith, \& BetsAnn, 1991). The importance of teacher engagement has increased in the 21 st century. Millennial students need teachers to be more sensitive to their competencies, to help develop a culture of self-assessment and enhancing abilities.

The concept of engagement is one that has been studied significantly, as it is closely related to work processes and outcomes (Dulagil, 2012),(Torrente, Salanova, Llorens, \& Schaufeli, 2012). Engagement relates to a person's overall investment in himself, which shows a comprehensive relationship with his performance (Crawford, 2018). Involvement is linked to sources of work and performance, because engagement shows control over decisions and their work (Chung \& Angeline, 2010). This concept fits perfectly with the teaching profession. Teachers in Indonesia are professional educators with the main task of educating, teaching, guiding, directing, training, assessing, and evaluating students in early childhood education in formal, primary, and secondary education (Undang Undang Republik Indonesia No 14 Tahun 2005 tentang Guru dan Dosen, 2005). The concept of teacher engagement is considered appropriate to describe Indonesian teachers with complex tasks and responsibilities. To improve the quality of education in Indonesia, it is necessary for teachers to be involved in accordance with the Indonesian context and absorb all positive aspects in the concept of engagement as a whole (Sasmoko, Doringin, Indrianti, Goni, \& Ruliana, 2018).

The presence of a self-diagnostic application for teachers is very important, so that teachers can carry out self-assessments to quickly shape their level of involvement via smartphones. Thus, technological developments can also be perceived as an early detection method for teachers to determine which programs are most needed to improve competence and engagement (Sasmoko, Noerlina, Indrianti, Permai, \& Manalu, 2018).

Some intervention designs related to meaningfulness to increase teacher engagement are through Meaningful and Fulfilling Education programs, Meaningful and Fulfilling Work Life, Meaningful and Fulfilling Character, and Meaningful and Fulfilling Leaders (Rabiha, Sasmoko, \& Indrianti, 2019). 


\section{Methodology.}

\subsection{Community Service Methods}

The method used in community service is Quasi Experiment (Gribbons \& Herman, 1997),(Flammer \& Luo, 2016) through Post Test Only Random Design (Dimitrov \& Rumrill, 2003). Intervention in the community with the Video Intervention Program on teacher empowerment is becoming increasingly engaged. The populations that were intervened were primary school teachers in Jakarta, Bekasi and South Tangerang. Sampling technique with accidental sampling with a total sample of 79 elementary school teachers. Data collection techniques on the success of the video intervention program with a Likert Scale ranging from 1 to 5.

\section{Result and Discussion}

\subsection{First Outcome}

Implementation of engagement for elementary school teachers in Jakarta, Bekasi and South Tangerang through the Video Intervention Program.

Based on initial exploration, it was found that elementary school teachers worked hard but tended to be workaholics. Teachers do not experience a balance between work and their quality of life. In this case, ideally the teacher as a professional profession should be engaged in the teacher. For this reason, an intervention program through video was prepared. In the intervention process, in the first stage the teachers enjoyed the intervention video. The second stage, after enjoying the intervention video, then the teacher fills in the teacher's self-assessment instrument regarding teacher engagement.

\subsection{Second Outcome}

Elementary school teachers in Jakarta, Bekasi and South Tangerang after enjoying the Video Intervention Program tend to experience significant engagement In proving the success of the Video Intervention Program, the PkM team in this case determined 3 (three) categories of teacher self-assessment regarding teacher engagement, namely: (a) workacholic, (b) engage, and (c) highly engaged. Data analysis was performed with a confidence interval at the 5\% significance level, and the results are as shown in Table 1 below.

Table 1: Calculation of the Confidence Interval Impact of the Video Intervention Program on Teacher SelfAssessment of Teacher Engagement

Descriptives

\begin{tabular}{|c|c|c|c|c|}
\hline & & & Statistic & Std. Error \\
\hline \multirow[t]{13}{*}{ UTE } & Mean & & 46.4304 & .23190 \\
\hline & \multirow{2}{*}{$\begin{array}{l}95 \% \text { Confidence Interval } \\
\text { for Mean }\end{array}$} & Lower Bound & 45.9687 & \\
\hline & & Upper Bound & 46.8920 & \\
\hline & $5 \%$ Trimmed Mean & & 46.6174 & \\
\hline & Median & & 47.0000 & \\
\hline & Variance & & 4.248 & \\
\hline & Std. Deviation & & 2.06114 & \\
\hline & Minimum & & 40.00 & \\
\hline & Maximum & & 50.00 & \\
\hline & Range & & 10.00 & \\
\hline & Interquartile Range & & 2.00 & \\
\hline & Skewness & & -1.367 & .271 \\
\hline & Kurtosis & & 2.474 & .535 \\
\hline
\end{tabular}

Based on Table 1 above, the resulting lower bound is 45.4304 and an upper bound is 46.9920 . So the teachers of SD Jakarta, Bekasi and Tangerang Selatan after enjoying the Video Intervention Program tend to have engaged significantly at $\alpha<0.05$. 
In order for the teacher to be able to achieve more than engage, then analyzed with the Binary Segmentation analysis approach and set Prunning Depth of 2, Prunning Parent of 2, and Prunning Child of 1 , with a significance level of $\alpha<0.05$. The result is as shown in Figure 1 below.

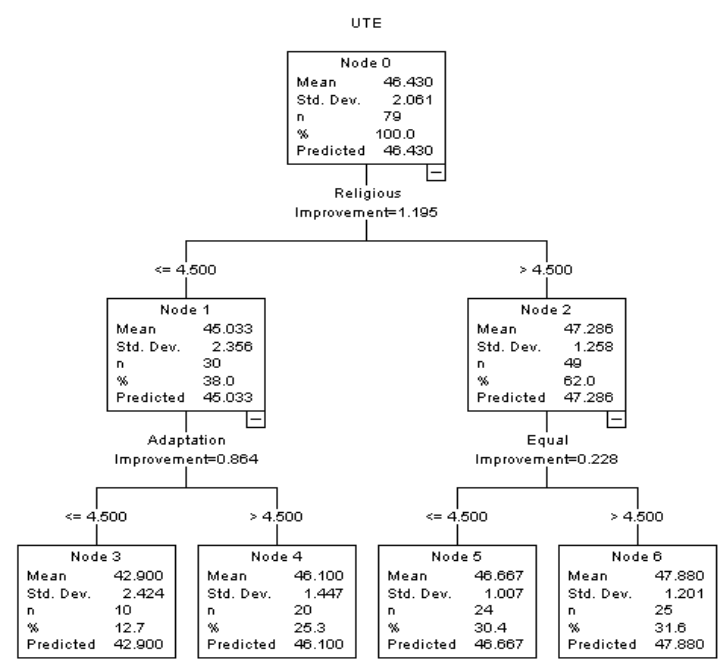

Figure 1. Binary Segmentation Determining Teacher Engagement Empowerment for Elementary School Teachers in Jakarta, Bekasi and South Tangerang After Enjoying the Video Intervention Program

From Figure 1, it can be interpreted that the Video Intervention Program will further increase the engagement of teachers in Jakarta, Bekasi and South Tangerang, if these teachers improve in practicing religion in carrying out religious orders. Because it will be able to increase teacher engagement by 1.195 times from the current condition.

\subsection{Third Outcome}

If it is seen from the difference between the city of origin and education, it is evident that elementary school teachers in Jakarta, Bekasi, and Tangerang Selatan both tend to engage significantly at $\alpha<0.05$. It was also found that female teachers were more engaged than male teachers with a t value of 2.193, which is significant at $\alpha<0.05$.

\section{Conclusion.}

Based on the results of the trials conducted, it can be concluded that the engagement of elementary school teachers in Jakarta, Bekasi and South Tangerang can be increased through the Video Intervention Program. After empowering teachers through the Video Intervention Program, elementary school teachers in Jakarta, Bekasi and South Tangerang experienced significant engagement at $\alpha<0.05$. Furthermore, through the results of the self-assessment, it was found that teacher empowerment through the Video Intervention Program would further increase teacher engagement in Jakarta, Bekasi and South Tangerang, if these teachers improve themselves in carrying out religious orders (Religious), because it will be able to increase teacher engagement by 1.195 times the condition. currently. In addition, it was found that female teachers were more engaged than male teachers with a $t$ value of 2.193 which was significant at $\alpha<0.05$.

\section{References}

Beairsto Bruce. (2012). Teacher Engagement is the Key to Student Engagement. Retrieved from https://www.edcan.ca/articles/teacher-engagement-is-the-key-to-student-engagement/

Chung, N. G., \& Angeline, T. K. (2010). Does work engagement mediate the relationship between job resources and job performance of employees.

Crawford, E. R. (2018). Job Engagement: Antecedents and Effects on Job Performance JOB ENGAGEMENT : ANTECEDENTS AND EFFECTS ON JOB PERFORMANCE. Academy of 
Management Journal, 53(February), 617-635. https://doi.org/10.5465/AMJ.2010.51468988

Dimitrov, D. M., \& Rumrill, P. D. (2003). Pretest-posttest designs and measurement of change, 20, $159-165$.

Dulagil, A. (2012). The relationship of employee engagement and wellbeing to organisational and student outcomes. SBS HDR Student Conference, 1.

Flammer, C., \& Luo, J. (2016). CORPORATE SOCIAL RESPONSIBILITY AS AN EMPLOYEE GOVERNANCE TOOL : EVIDENCE FROM A QUASI-EXPERIMENT, (September 2014). https://doi.org/10.1002/smj

Gribbons, B., \& Herman, J. (1997). True and Quasi-Experimental Designs True and QuasiExperimental Designs ., 5(1996), 1996-1997.

Louis, Seashore, K., Smith, \& BetsAnn. (1991). RESTRUCTURING, TEACHER ENGAGEMENT AND SCHOOL CULTURE: Perspectives on School Reform and The Improvement of Teacher's Work. In Office of Educational Research and Improvement (ED), Washington, DC. (Vol. 91, pp. 399-404).

Rabiha, S. G., Sasmoko, \& Indrianti, Y. (2019). Implementation of K-Nearest Neighbor for Classification Teacher Engagement Profiling and Interventions. In 2019 International Congress on Applied Information Technology (AIT) (pp. 1-6).

Sasmoko, Doringin, F., Indrianti, Y., Goni, A. M., \& Ruliana, P. (2018). Indonesian Teacher Engagement Index (ITEI): An Emerging Concept of Teacher Engagement in Indonesia. IOP Conference Series: Materials Science and Engineering, 306(1). https://doi.org/10.1088/1757$899 X / 306 / 1 / 012119$

Sasmoko, Noerlina, Indrianti, Y., Permai, S. D., \& Manalu, S. R. (2018). APPLYING INDONESIAN TEACHER ENGAGEMENT INDEX (ITEI) APPS: SELF-DIAGNOSTIC. ICIC International, 9(3).

Suleman, Q. (2012). Comparative Study of the Contemporary and Former Educational Management Systems at Elementary and Secondary Education at District Level in Khyber Pukhtunkhwa ( Pakistan ), 48(48), 28-51.

Suparlan, D., \& Ed, M. (2005). Menjadi Guru Efektif. Yogyakarta: Hikayat.

Torrente, P., Salanova, M., Llorens, S., \& Schaufeli, W. B. (2012). Teams make it work: How team work engagement mediates between social resources and performance in teams. In Psicothema 2012 (Vol. 24, pp. 106-112). Retrieved from www.psicothema.com

Undang Undang Republik Indonesia No 14 Tahun 2005 tentang Guru dan Dosen. (2005). 


\title{
EMPOWERING TEACHER ENGAGEMENT IN PRIMARY SCHOOLS THROUGH VIDEO INTERVENTION PROGRAM
}

\author{
${ }^{1}$ Sucianna Ghadati Rabiha, ${ }^{2}$ Sasmoko, ${ }^{3}$ Yasinta Indrianti \\ ${ }^{1}$ Binus Online Learning \& Research Interest Group in Educational \\ Technology, Information Systems Department. \\ ${ }^{2}$ Primary Teacher Education Department, Faculty Humanities \& Research Interest Group in \\ Educational Technology \\ ${ }^{3}$ Research Interest Group in Educational Technology, \\ Bina Nusantara University \\ *sasmoko@binus.edu
}

Received: January $19^{\text {th }}, 2021 /$ Revised: February $18^{\text {th }}$ 2021/ Accepted: March $12^{\text {th }}, 2021$

\begin{abstract}
Teacher engagement basically shows that the personal and existence of a qualified teacher is positioned not only as a teacher but as an integrated whole of an educator who is professional and has an Indonesian character. This concept is in line with the mandate of the 2015-2019 RPJMN as stipulated in the Ministry of Research and Technology Strategic Plan where the government seeks to strengthen overall development by emphasizing the development of economic competitive advantages, one of which is based on quality institutions and resources. Based on the results of the trials conducted, it can be concluded that the engagement of elementary school teachers in Jakarta, Bekasi and South Tangerang can be increased through the Video Intervention Program. After empowering teachers through the Video Intervention Program, elementary school teachers in Jakarta, Bekasi and South Tangerang experienced significant engagement at $\alpha<0.05$. Furthermore, through the results of the self-assessment, it was found that teacher empowerment through the Video Intervention Program will further increase teacher engagement in Jakarta, Bekasi and South Tangerang, if these teachers improve themselves in carrying out religious orders.
\end{abstract}

Keywords: teacher engagement, self-assessment

\section{Introduction.}

A study states that current education management must position itself as a modern educational management capable of implementing a reward and punishment system so as to ensure excellent performance from teachers and institutions to strengthen results and productivity (Suleman, 2012). Teachers in Indonesia are professional educators with the main task of educating, teaching, guiding, directing, training, assessing, and evaluating students in early childhood education formal education, basic education and secondary education (Undang Undang Republik Indonesia No 14 Tahun 2005 tentang Guru dan Dosen, 2005). The existence of teachers in Indonesia is very important in improving the standard of living of the nation by involving all spiritual, emotional, intellectual, physical and other aspects (Suparlan \& Ed, 2005).

Teacher engagement basically shows that the personal and existence of a qualified teacher is positioned not only as a teacher but as a whole as a professional educator with Indonesian character. This concept is in line with the mandate of the third RPJMN for 2015-2019 which is stated in the Ministry of Research, Technology and Higher Education's Strategic Plan where the government seeks to solidify overall development by emphasizing the development of competitive economic advantages, one of which is based on quality institutions and resources. 
This effort provides benefits for every education actor starting from the Ministry of Education and Culture of the Republic of Indonesia, especially the Directorate General of Primary and Secondary Education, formal education institutions and the human resources involved. These benefits are in the form of anatomical portraits of teachers and educational institutions so that appropriate interventions are obtained in order to improve sustainable quality. Based on the analysis, the aim of this Community Service is to carry out "Empowerment of Primary School Teacher Engagement in Jakarta, Bekasi and South Tangerang".

A synergistic effort to achieve the best student achievement as an indicator of the quality of education is the full and deep involvement and engagement of the teacher as the key (Beairsto Bruce, 2012). This community service program tries to build a teacher engagement construct in the Indonesian context in accordance with the Third RPJMN 2015-2019, the Ministry of Research, Technology and Higher Education Strategic Plan and also the 2015-2019 Bina Nusantara University Research Strategic Plan, so that it is able to detect early portraits of teachers in Indonesia, especially primary school teachers in Jakarta, Bekasi and South Tangerang.

Through the Community Service Program, we try to provide an understanding regarding Teacher Engagement through Intervention Videos that we share on YouTube. So that teachers can understand the concepts in Teacher Engagement. In addition, we also ask for feedback from teachers to conduct self-assessment of understanding related to Teacher Engagement through the google form application. With early detection, it will be followed by the ability to make relatively appropriate interventions as a strategic effort in building 21 st century teachers who are ready to compete internationally and be able to produce quality future generations.

\section{Literature Review.}

The Indonesian teachers involved are positioned not only as teachers, but also helping to shape the professional characteristics of an Indonesian educator model. Research on teacher engagement proves that it has a positive impact on student education. Engaged teachers can also make students more involved, thus creating a more effective learning atmosphere (Louis, Seashore, Smith, \& BetsAnn, 1991). The importance of teacher engagement has increased in the 21 st century. Millennial students need teachers to be more sensitive to their competencies, to help develop a culture of self-assessment and enhancing abilities.

The concept of engagement is one that has been studied significantly, as it is closely related to work processes and outcomes (Dulagil, 2012),(Torrente, Salanova, Llorens, \& Schaufeli, 2012). Engagement relates to a person's overall investment in himself, which shows a comprehensive relationship with his performance (Crawford, 2018). Involvement is linked to sources of work and performance, because engagement shows control over decisions and their work (Chung \& Angeline, 2010). This concept fits perfectly with the teaching profession. Teachers in Indonesia are professional educators with the main task of educating, teaching, guiding, directing, training, assessing, and evaluating students in early childhood education in formal, primary, and secondary education (Undang Undang Republik Indonesia No 14 Tahun 2005 tentang Guru dan Dosen, 2005). The concept of teacher engagement is considered appropriate to describe Indonesian teachers with complex tasks and responsibilities. To improve the quality of education in Indonesia, it is necessary for teachers to be involved in accordance with the Indonesian context and absorb all positive aspects in the concept of engagement as a whole (Sasmoko, Doringin, Indrianti, Goni, \& Ruliana, 2018).

The presence of a self-diagnostic application for teachers is very important, so that teachers can carry out self-assessments to quickly shape their level of involvement via smartphones. Thus, technological developments can also be perceived as an early detection method for teachers to determine which programs are most needed to improve competence and engagement (Sasmoko, Noerlina, Indrianti, Permai, \& Manalu, 2018).

Some intervention designs related to meaningfulness to increase teacher engagement are through Meaningful and Fulfilling Education programs, Meaningful and Fulfilling Work Life, Meaningful and Fulfilling Character, and Meaningful and Fulfilling Leaders (Rabiha, Sasmoko, \& Indrianti, 2019). 


\section{Methodology.}

\subsection{Community Service Methods}

The method used in community service is Quasi Experiment (Gribbons \& Herman, 1997),(Flammer \& Luo, 2016) through Post Test Only Random Design (Dimitrov \& Rumrill, 2003). Intervention in the community with the Video Intervention Program on teacher empowerment is becoming increasingly engaged. The populations that were intervened were primary school teachers in Jakarta, Bekasi and South Tangerang. Sampling technique with accidental sampling with a total sample of 79 elementary school teachers. Data collection techniques on the success of the video intervention program with a Likert Scale ranging from 1 to 5.

\section{Result and Discussion}

\subsection{First Outcome}

Implementation of engagement for elementary school teachers in Jakarta, Bekasi and South Tangerang through the Video Intervention Program.

Based on initial exploration, it was found that elementary school teachers worked hard but tended to be workaholics. Teachers do not experience a balance between work and their quality of life. In this case, ideally the teacher as a professional profession should be engaged in the teacher. For this reason, an intervention program through video was prepared. In the intervention process, in the first stage the teachers enjoyed the intervention video. The second stage, after enjoying the intervention video, then the teacher fills in the teacher's self-assessment instrument regarding teacher engagement.

\subsection{Second Outcome}

Elementary school teachers in Jakarta, Bekasi and South Tangerang after enjoying the Video Intervention Program tend to experience significant engagement In proving the success of the Video Intervention Program, the PkM team in this case determined 3 (three) categories of teacher self-assessment regarding teacher engagement, namely: (a) workacholic, (b) engage, and (c) highly engaged. Data analysis was performed with a confidence interval at the 5\% significance level, and the results are as shown in Table 1 below.

Table 1: Calculation of the Confidence Interval Impact of the Video Intervention Program on Teacher SelfAssessment of Teacher Engagement

Descriptives

\begin{tabular}{|c|c|c|c|c|}
\hline & & & Statistic & Std. Error \\
\hline \multirow[t]{13}{*}{ UTE } & Mean & & 46.4304 & .23190 \\
\hline & \multirow{2}{*}{$\begin{array}{l}95 \% \text { Confidence Interval } \\
\text { for Mean }\end{array}$} & Lower Bound & 45.9687 & \\
\hline & & Upper Bound & 46.8920 & \\
\hline & $5 \%$ Trimmed Mean & & 46.6174 & \\
\hline & Median & & 47.0000 & \\
\hline & Variance & & 4.248 & \\
\hline & Std. Deviation & & 2.06114 & \\
\hline & Minimum & & 40.00 & \\
\hline & Maximum & & 50.00 & \\
\hline & Range & & 10.00 & \\
\hline & Interquartile Range & & 2.00 & \\
\hline & Skewness & & -1.367 & .271 \\
\hline & Kurtosis & & 2.474 & .535 \\
\hline
\end{tabular}

Based on Table 1 above, the resulting lower bound is 45.4304 and an upper bound is 46.9920 . So the teachers of SD Jakarta, Bekasi and Tangerang Selatan after enjoying the Video Intervention Program tend to have engaged significantly at $\alpha<0.05$. 
In order for the teacher to be able to achieve more than engage, then analyzed with the Binary Segmentation analysis approach and set Prunning Depth of 2, Prunning Parent of 2, and Prunning Child of 1 , with a significance level of $\alpha<0.05$. The result is as shown in Figure 1 below.

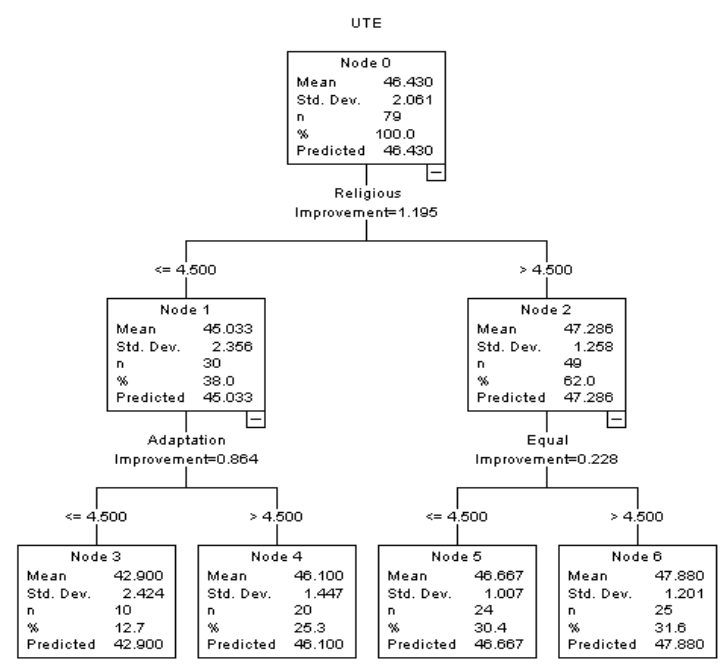

Figure 1. Binary Segmentation Determining Teacher Engagement Empowerment for Elementary School Teachers in Jakarta, Bekasi and South Tangerang After Enjoying the Video Intervention Program

From Figure 1, it can be interpreted that the Video Intervention Program will further increase the engagement of teachers in Jakarta, Bekasi and South Tangerang, if these teachers improve in practicing religion in carrying out religious orders. Because it will be able to increase teacher engagement by 1.195 times from the current condition.

\subsection{Third Outcome}

If it is seen from the difference between the city of origin and education, it is evident that elementary school teachers in Jakarta, Bekasi, and Tangerang Selatan both tend to engage significantly at $\alpha<0.05$. It was also found that female teachers were more engaged than male teachers with a t value of 2.193, which is significant at $\alpha<0.05$.

\section{Conclusion.}

Based on the results of the trials conducted, it can be concluded that the engagement of elementary school teachers in Jakarta, Bekasi and South Tangerang can be increased through the Video Intervention Program. After empowering teachers through the Video Intervention Program, elementary school teachers in Jakarta, Bekasi and South Tangerang experienced significant engagement at $\alpha<0.05$. Furthermore, through the results of the self-assessment, it was found that teacher empowerment through the Video Intervention Program would further increase teacher engagement in Jakarta, Bekasi and South Tangerang, if these teachers improve themselves in carrying out religious orders (Religious), because it will be able to increase teacher engagement by 1.195 times the condition. currently. In addition, it was found that female teachers were more engaged than male teachers with a $t$ value of 2.193 which was significant at $\alpha<0.05$.

\section{References}

Beairsto Bruce. (2012). Teacher Engagement is the Key to Student Engagement. Retrieved from https://www.edcan.ca/articles/teacher-engagement-is-the-key-to-student-engagement/

Chung, N. G., \& Angeline, T. K. (2010). Does work engagement mediate the relationship between job resources and job performance of employees.

Crawford, E. R. (2018). Job Engagement: Antecedents and Effects on Job Performance JOB ENGAGEMENT : ANTECEDENTS AND EFFECTS ON JOB PERFORMANCE. Academy of 
Management Journal, 53(February), 617-635. https://doi.org/10.5465/AMJ.2010.51468988

Dimitrov, D. M., \& Rumrill, P. D. (2003). Pretest-posttest designs and measurement of change, 20, $159-165$.

Dulagil, A. (2012). The relationship of employee engagement and wellbeing to organisational and student outcomes. SBS HDR Student Conference, 1.

Flammer, C., \& Luo, J. (2016). CORPORATE SOCIAL RESPONSIBILITY AS AN EMPLOYEE GOVERNANCE TOOL : EVIDENCE FROM A QUASI-EXPERIMENT, (September 2014). https://doi.org/10.1002/smj

Gribbons, B., \& Herman, J. (1997). True and Quasi-Experimental Designs True and QuasiExperimental Designs ., 5(1996), 1996-1997.

Louis, Seashore, K., Smith, \& BetsAnn. (1991). RESTRUCTURING, TEACHER ENGAGEMENT AND SCHOOL CULTURE: Perspectives on School Reform and The Improvement of Teacher's Work. In Office of Educational Research and Improvement (ED), Washington, DC. (Vol. 91, pp. 399-404).

Rabiha, S. G., Sasmoko, \& Indrianti, Y. (2019). Implementation of K-Nearest Neighbor for Classification Teacher Engagement Profiling and Interventions. In 2019 International Congress on Applied Information Technology (AIT) (pp. 1-6).

Sasmoko, Doringin, F., Indrianti, Y., Goni, A. M., \& Ruliana, P. (2018). Indonesian Teacher Engagement Index (ITEI): An Emerging Concept of Teacher Engagement in Indonesia. IOP Conference Series: Materials Science and Engineering, 306(1). https://doi.org/10.1088/1757$899 X / 306 / 1 / 012119$

Sasmoko, Noerlina, Indrianti, Y., Permai, S. D., \& Manalu, S. R. (2018). APPLYING INDONESIAN TEACHER ENGAGEMENT INDEX (ITEI) APPS: SELF-DIAGNOSTIC. ICIC International, 9(3).

Suleman, Q. (2012). Comparative Study of the Contemporary and Former Educational Management Systems at Elementary and Secondary Education at District Level in Khyber Pukhtunkhwa ( Pakistan ), 48(48), 28-51.

Suparlan, D., \& Ed, M. (2005). Menjadi Guru Efektif. Yogyakarta: Hikayat.

Torrente, P., Salanova, M., Llorens, S., \& Schaufeli, W. B. (2012). Teams make it work: How team work engagement mediates between social resources and performance in teams. In Psicothema 2012 (Vol. 24, pp. 106-112). Retrieved from www.psicothema.com

Undang Undang Republik Indonesia No 14 Tahun 2005 tentang Guru dan Dosen. (2005). 